\title{
Model Pembelajaran Interaktif dan Keterampilan Sosial terhadap Hasil Belajar Kognitif Siswa pada Pembelajaran Sejarah di SMA
}

\author{
Ririk Ajeng Alfianti ${ }^{1}$, Blasius Suprapta ${ }^{1}$, Endang Sri Andayani ${ }^{2}$ \\ ${ }^{1}$ Pendidikan Sejarah-Universitas Negeri Malang \\ ${ }^{2}$ Akuntansi-Universitas Negeri Malang
}

\section{INFO ARTIKEL}

\section{Riwayat Artikel:}

Diterima: 13-03-2019

Disetujui: 24-07-2019

\author{
Kata kunci: \\ interactive learning models; \\ social skills; \\ cognitive learning outcomes; \\ history learning; \\ model pembelajaran interaktif; \\ keterampilan sosial; \\ hasil belajar kognitif: \\ pembelajaran sejarah
}

\author{
Alamat Korespondensi: \\ Ririk Ajeng Alfianti \\ Pendidikan Sejarah \\ Universitas Negeri Malang \\ Jalan Semarang 5 Malang \\ E-mail: ririkajeng507@gmail.com
}

\begin{abstract}
ABSTRAK
Abstract: This research aims to determine the effect of interactive learning models on student cognitive learning outcomes, determine the effect of social skills on students 'cognitive learning outcomes, and determine the effect of interaction between interactive learning models and social skills on students' cognitive learning outcomes in history learning in high school. This research was a quasi-experimental with factorial design. The research samples were class X IPS 2 as an experimental class and class X IPS 3 as a control at SMAN 1 Gondanglegi. The research instruments were test, questionnaire, and learning implementation observation sheet. Data analysis technique was two-way ANOVA. The results of this research shows that there is is impact on the use of interactive learning models on student cognitive learning outcomes, there is impact of students' social skills on student cognitive learning outcomes, and there is impact of the interaction between interactive learning models and social skills on student cognitive learning outcomes.

Abstrak: Penelitian ini bertujuan untuk mengetahui pengaruh model pembelajaran interaktif terhadap hasil belajar kognitif siswa, mengetahui pengaruh keterampilan sosial terhadap hasil belajar kognitif siswa, dan mengetahui pengaruh interaksi antara model pembelajaran interaktif dan keterampilan sosial terhadap hasil belajar kognitif siwa dalam pembelajaran sejarah di SMA. Bentuk penelitian ini adalah eksperimen semu dengan desain faktorial. Sampel penelitian adalah kelas X IPS 2 sebagai kelas eksperimen dan kelas X IPS 3 sebagai kelas kontrol di SMAN 1 Gondanglegi. Instrumen yang digunakan adalah tes, angket, dan lembar observasi keterlaksanaan pembelajaran. Teknik analisis data menggunakan anova dua jalur. Hasil penelitian menunjukkan bahwa ada pengaruh penggunaan model pembelajaran interaktif terhadap hasil belajar kognitif siswa, ada pengaruh keterampilan sosial terhadap hasil belajar kognitif siswa dan ada pengaruh interaksi antara model pembelajaran interaktif dan keterampilan sosial terhadap hasil belajar kognitif siswa.
\end{abstract}

Permasalahan umum dalam pembelajaran sejarah di sekolah menengah adalah siswa sulit untuk berperan aktif dalam pembelajaran, masih didominasi oleh peran aktif guru, dan selalu menggunakan model pembelajaran konvensional. Akibatnya adalah siswa sangat bergantung pada guru dalam menerima materi pelajaran, siswa bosan dalam mengikuti pembelajaran, dan banyak siswa yang memperoleh nilai dibatas KKM. Hasil belajar kognitif merupakan salah satu output yang penting dalam proses pembelajaran sehingga permasalahan tersebut perlu diperhatikan oleh guru. Melalui hasil belajar, guru bisa mengetahui tingkat penguasaan materi yang telah dipelajari oleh siswa dan untuk mengetahui keberhasilan proses pembelajaran sesuai dengan standar kompetensi yang ada (Arifin, 2014). Salah satu faktor penyebab kurangnya ketercapaian hasil belajar siswa adalah penggunaan model pembelajaran. (Sayono, 2015) menyebutkan bahwa dalam pembelajaran sejarah perlu diterapkan model-model pembelajaran yang menantang untuk mengembangkan kemampuan berpikir, sikap, dan kepribadian siswa.

Salah satu model pembelajaran yang bisa digunakan oleh guru dalam pembelajaran sejarah adalah model pembelajaran interaktif. Model pembelajaran interaktif merupakan salah satu jenis pembelajaran kooperatif yang didalamnya terdapat kegiatan diskusi dan saling berbagi antar siswa serta dapat meningkatkan rasa ingin tahu, sikap kritis, dan kreativitas siswa (Firmansyah \& Kurniawan, 2017). Pada model pembelajaran interaktif terdapat interaksi antara guru dengan siswa, siswa dengan siswa, dan 
siswa dengan sumber belajar. Berdasarkan teori konstruktivistik sosial Vygotsky, lingkungan sosial sangat penting dalam proses pembelajaran untuk membantu membangun sendiri apa yang mereka pahami dan pelajari. Interaksi sosial yang dilakukan siswa dalam proses pembelajaran dapat mengubah atau membentuk pengalaman-pengalaman belajar siswa dan mengembangkan sisi kognitif mereka (Schunk, 2012). Model pembelajaran interaktif diduga efektif jika diterapkan dalam pembelajaran sejarah karena adanya interaksi antara guru dengan siswa, siswa dengan siswa, dan siswa dengan sumber belajar sehingga siswa akan secara bersama-sama membangun sendiri pengetahuannya. (Fitriani, Wahjoedi, \& Towaf, 2017) pembelajaran kooperatif dapat mengembangkan paling sedikit tiga tujuan penting, yaitu prestasi akademik, toleransi, dan penerimanaan keanekaragaman.

Faktor lain yang diduga bisa memengaruhi hasil belajar adalah keterampilan sosial. Keterampilan sosial adalah kemampuan untuk berinteraksi dengan keadaan di lingkungan sekitarnya sehingga dapat bertingkah laku sesuai dengan kondisi atau dengan kata lain dapat menyesuaikan diri dengan lingkungannya. (Bremer \& Smith, 2004) menyebutkan bahwa keterampilan sosial dapat menjadi faktor penentu keberhasilan seseorang di berbagai bidang, salah satunya bidang pendidikan. Pada proses pembelajaran, khususnya dalam Kurikulum 2013 membutuhkan peran aktif siswa yang akan berlangsung dengan baik jika siswa memiliki keterampilan sosial yang baik.

Pada pembelajaran sejarah, siswa belajar tentang kehidupan di masa lalu. Pengetahuan masa lampau mengandung nilainilai kearifan yang dapat digunakan untuk melatih kesadaran membentuk sikap, watak, dan kepribadian siswa (Aman, 2011). Berdasarkan pendapat ini, maka siswa yang telah mengikuti pembelajaran sejarah akan bertindak sesuai dengan konsep-konsep sejarah termasuk dalam melakukan keterampilan sosial. Model pembelajaran interaktif dan keterampilan sosial merupakan dua hal yang berkaitan karena dalam penerapan model pembelajaran interaktif terdapat interaksi sosial yang membutuhkan keterampilan sosial siswa. Kedua hal ini jika dilakukan dengan baik akan menjadikan pembelajaran lebih efektif sehingga dapat memengaruhi hasil belajar siswa.

Penelitian yang relevan dengan kajian di atas adalah penelitian dari (Vella \& Caruana, 2015) yang menunjukkan bahwa penerapan model pembelajaran interaktif dalam pembelajaran sejarah dapat meningkatkan hasil belajar psikomotorik siswa, namun masih memiliki keterbatasan yaitu tidak menunjukkan faktor lain yang mengakibatkan berhasilnya perlakuan. Penelitian lain yang relevan adalah penelitian dari (Pada, 2016) yang menunjukkan bahwa ada perbedaan hasil belajar kognitif yang belajar dengan menggunakan model pembelajaran interaktif dibanding dengan siswa yang menggunakan model pembelajaran langsung. Penelitian yang relevan lainnya adalah penelitian dari (Sutomo, 2016; Wahid, 2015), namun masih terdapat hasil penelitian yang belum konsisten sehingga dalam penelitian ini akan memadukan model pembelajaran interaktif dan keterampilan sosial untuk melihat pengaruhnya terhadap hasil belajar kognitif siswa dalam pembelajaran sejarah.

\section{METODE}

Penelitian ini merupakan penelitian kuantitatif dengan menggunakan metode eksperimen dalam bentuk quasi experimental design. Bentuk eksperimen semu digunakan karena menggunakan kelompok kelas yang sudah terbentuk sebelumnya (Creswell, 2010). Desain penelitian eksperimen yang digunakan adalah factorial design. Desain faktorial digunakan karena pada penelitian ini memperhatikan adanya variabel moderator yang memengaruhi perlakuan yang diberikan oleh variabel bebas terhadap variabel terikat (Sugiyono, 2012). Rancangan desain faktorial pada penelitian ini dapat dilihat pada tabel 1.

Tabel 1. Rancangan Desain Faktorial

\begin{tabular}{lcc}
\hline \multicolumn{1}{c}{ Keterampilan Sosial } & Interaktif $\left(\mathbf{A}_{\mathbf{1}}\right)$ & Konvensional $\left(\mathbf{A}_{2}\right)$ \\
\hline Keterampilan Sosial Sangat Tinggi $\left(\mathrm{B}_{1}\right)$ & $\mathrm{A}_{1} \mathrm{~B}_{1}$ & $\mathrm{~A}_{2} \mathrm{~B}_{1}$ \\
Keterampilan Sosial Tinggi $\left(\mathrm{B}_{2}\right)$ & $\mathrm{A}_{1} \mathrm{~B}_{2}$ & $\mathrm{~A}_{2} \mathrm{~B}_{2}$ \\
Keterampilan Sosial Sedang $\left(\mathrm{B}_{3}\right)$ & $\mathrm{A}_{1} \mathrm{~B}_{3}$ & $\mathrm{~A}_{2} \mathrm{~B}_{3}$ \\
Keterampilan Sosial Rendah $\left(\mathrm{B}_{4}\right)$ & $\mathrm{A}_{1} \mathrm{~B}_{4}$ & $\mathrm{~A}_{2} \mathrm{~B}_{4}$ \\
\hline
\end{tabular}

$\mathrm{A}_{1} \mathrm{~B}_{1}$ : rata-rata hasil belajar kelompok siswa yang menggunakan model pembelajaran interaktif dengan keterampilan sosial sangat tinggi. $A_{1} B_{2}$ : rata-rata hasil belajar kelompok siswa yang menggunakan model pembelajaran interaktif dengan keterampilan sosial tinggi. $\mathrm{A}_{1} \mathrm{~B}_{3}$ : rata-rata hasil belajar kelompok siswa yang menggunakan model pembelajaran interaktif dengan keterampilan sosial sedang. $\mathrm{A}_{1} \mathrm{~B}_{4}$ : rata-rata hasil belajar kelompok siswa yang menggunakan model pembelajaran interaktif dengan keterampilan sosial rendah. $\mathrm{A}_{2} \mathrm{~B}_{1}$ : rata-rata hasil belajar kelompok siswa yang menggunakan model pembelajaran konvensional dengan keterampilan sosial sangat tinggi. $A_{2} B_{2}$ : rata-rata hasil belajar kelompok siswa yang menggunakan model pembelajaran konvensional dengan keterampilan sosial tinggi $\mathrm{A}_{2} \mathrm{~B}_{3}$ : rata-rata hasil belajar kelompok siswa yang menggunakan model pembelajaran konvensional dengan keterampilan sosial sedang. $\mathrm{A}_{2} \mathrm{~B}_{4}$ : rata-rata hasil belajar kelompok siswa yang menggunakan model pembelajaran konvensional dengan keterampilan sosial rendah.

Populasi penelitian ini adalah seluruh siswa kelas X SMA Negeri 1 Gondanglegi pada Tahun Ajaran 2018/2019 dan sebagai sampel adalah kelas X IPS 2 sebagai kelas eksperimen dan kelas X IPS 3 sebagai kelas kontrol. Variabel bebas dalam penelitian ini adalah model pembelajaran interaktif dan keterampilan sosial, sedangkan variabel terikatnya adalah hasil belajar 
kognitif. Instrumen yang digunakan dalam penelitian ini adalah tes dalam bentuk pilihan ganda, angket keterampilan sosial siswa dan observasi keterlaksanaan pembelajaran. Indikator keterampilan sosial siswa adalah environmental, interpersonal, self related, and task related behaviors (Cartledge \& Milburn, 1980) yang dipadukan dengan konsep sejarah dan sasaran umum dalam pembelajaran sejarah. Kedua instrumen tersebut divalidasi oleh dosen ahli terlebih dahulu kemudian diuji cobakan. Instrumen yang telah diuji coba kemudian diuji validitas, reliabilitas, tingkat kesukaran soal, dan daya pembeda soal. Prosedur pengumpulan data pada penelitian ini adalah memberikan pretest dan angket keterampilan sosial di kedua kelompok kelas, memberikan perlakuan (treatment) yaitu pada kelas eksperimen menggunakan model pembelajaran interaktif dan pada kelas kontrol menggunakan model pembelajaran konvensional, dan memberikan post test di kedua kelompok kelas. Teknik analisis data yang digunakan adalah anova dua jalur dengan bantuan program SPSS.

\section{HASIL}

\section{Keterlaksanaan Proses Pembelajaran}

Keterlaksanaan proses pembelajaran merupakan hal yang penting dalam penelitian karena sebagai asumsi atau kontrol bahwa keberhasilan model pembelajaran dalam memengaruhi hasil belajar harus dilaksanakan guru sesuai dengan RPP yang dibuat. Hasil observasi keterlaksanaan proses pembelajaran menunjukkan bahwa guru sudah melaksanakan pembelajaran sesuai dengan sintaks pembelajaran pada RPP yang telah dibuat dengan sangat baik di kelas eksperimen yang menggunakan model pembelajaran interaktif maupun kelas kontrol yang menggunakan model pembelajaran konvensional.

\section{Deskripsi Variabel Penelitian}

Data keterampilan sosial yang diperoleh dari hasil angket dan hasil belajar kognitif siswa yang diperoleh dari hasil tes dapat dilihat pada tabel 2 .

Tabel 2. Rata-rata Keterampilan Sosial Siswa Pretest dan Posttest

\begin{tabular}{ccc}
\hline Data & Kelas Eksperimen & Kelas Kontrol \\
\hline Keterampilan Sosial Siswa & 42,48 & 42,44 \\
Pretest & 45,84 & 38,99 \\
Posttest & 84,98 & 78,43 \\
\hline
\end{tabular}

Berdasarkan tabel 2, dapat diketahui bahwa rata-rata keterampilan sosial siswa di kelas eksperimen 42,48 dan di kelas kontrol 42,44. Hasil angket keterampilan sosial siswa tersebut kemudian diuji dengan menggunakan uji Independent Sample ttest. Hasil uji Independent Sample t-test menunjukkan nilai Sig. (2-tailed) sebesar 0,989 > 0,05 sehingga dapat disimpulkan bahwa tingkat keterampilan sosial siswa di kedua kelompok kelas yaitu kelas eksperimen dan kelas kontrol adalah sama. Rata-rata hasil pretest siswa pada kelas eksperimen 45,84 dan pada kelas kontrol 38,99. Hasil pretest siswa ini kemudian diuji dengan menggunakan uji Independent Sample t-test. Hasil uji Independent Sample t-test diperoleh nilai Sig. (2-tailed) sebesar 0,079 > 0,05 sehingga dapat disimpulkan bahwa kemampuan awal siswa di kelas eksperimen dan kelas kontrol sama. Berdasarkan tabel 4 dapat diketahui rata-rata hasil posttest siswa di kelas eksperimen 84,98 dan di kelas kontrol 78,43.

\section{Uji Hipotesis}

Sebelum dilakukan uji hipotesis, terlebih dahulu dilakukan uji prasyarat yaitu uji normalitas dan uji homogenitas pada semua data hasil penelitian. Hasil uji normalitas dapat dilihat pada tabel 3 dan hasil uji homogenitas dapat dilihat pada tabel 4. Berdasarkan tabel 3 dapat diketahui bahwa semua data penelitian pada kelas eksperimen dan kelas kontrol berdistribusi normal karena nilai sig > 0,05. Hasil Uji homogenitas pada tabel 4 juga menunjukkan bahwa semua data penelitian homogen karena nilai sig > 0,05. Hasil kedua uji prasyarat tersebut menunjukkan bahwa data penelitian memenuhi syarat untuk dilakukan uji anova dua jalur dengan bantuan program SPSS. Data yang digunakan untuk uji hipotesis adalah data asli post test siswa dan bukan gain score karena hasil uji independent sample t-test yang telah dijelaskan di atas menunjukkan bahwa siswa di kedua kelompok kelas memiliki pengetahuan awal yang sama. Hasil uji hipotesis dengan menggunakan anova dua jalur dapat dilihat pada tabel 5.

Tabel 3. Uji Normalitas

\begin{tabular}{lcc}
\hline \multicolumn{1}{c}{ Data } & Kelas Eksperimen & Kelas Kontrol \\
\hline Angket Keterampilan Sosial & 0,088 & 0,501 \\
Pretest & 0,271 & 0,525 \\
Post Test & 0,293 & 0,336 \\
\hline
\end{tabular}


Tabel 4. Uji Homogenitas

\begin{tabular}{lc}
\hline \multicolumn{1}{c}{ Data } & Sig \\
\hline Angket Keterampilan Sosial & 0,065 \\
Pretest & 0,374 \\
Posttest & 0,447 \\
\hline
\end{tabular}

Tabel 5. Uji Anova Dua Jalur

\begin{tabular}{lccccc}
\hline \multicolumn{1}{c}{ Source } & Type III Sum of Squares & df & Mean Square & F & Sig \\
\hline Model Pembelajaran & 248,682 & 1 & 248,682 & 8,763 & 0,005 \\
Keterampilan Sosial & 711,637 & 3 & 237,212 & 8,359 & 0,000 \\
Model Pembelajaran Keterampilan Sosial & 270,156 & 3 & 90,052 & 3,173 & 0,032 \\
\hline
\end{tabular}

Berdasarkan tabel 5 dapat diketahui hasil uji anova dua jalur model pembelajaran diperoleh nilai Sig. sebesar $0,005<$ 0,05 sehingga Ho ditolak, artinya ada pengaruh positif signifikan penggunaan model pembelajaran interaktif terhadap hasil belajar siswa dalam pembelajaran sejarah. Hasil uji anova dua jalur keterampilan sosial diperoleh nilai Sig. sebesar 0,000 < 0,05 sehingga Ho ditolak, artinya ada pengaruh positif signifikan keterampilan sosial siswa terhadap hasil belajar siswa dalam pembelajaran sejarah. Hasil uji anova dua jalur model pembelajaran keterampilan sosial diperoleh nilai Sig. sebesar 0,032<0,05 sehingga Ho ditolak, artinya ada pengaruh positif signifikan interaksi antara model pembelajaran interaktif dan keterampilan sosial siswa terhadap hasil belajar siswa dalam pembelajaran sejarah.

Tabel 6. Uji Post Hoc

\begin{tabular}{|c|c|c|c|c|c|c|}
\hline \multirow{2}{*}{$\begin{array}{c}\text { (I) } \\
\text { Keterampilan Sosial }\end{array}$} & \multirow{2}{*}{$\begin{array}{c}(\mathbf{J}) \\
\text { Keterampilan Sosial }\end{array}$} & \multirow{2}{*}{ Mean Difference (I-J) } & \multirow{2}{*}{ Std. Error } & \multirow{2}{*}{ Sig. } & \multicolumn{2}{|c|}{ 95\% Confidence Interval } \\
\hline & & & & & Lower Bound & Upper Bound \\
\hline \multirow{3}{*}{ Rendah } & Sedang & 4,5758 & 2,34905 & 0,222 & $-1,6759$ & 10,8275 \\
\hline & Tinggi & $-6,0931^{*}$ & 2,07082 & 0,025 & $-11,6043$ & $-0,5818$ \\
\hline & Sangat Tinggi & $-5,6197$ & 2,44766 & 0,113 & $-12,1338$ & 0,8945 \\
\hline \multirow{3}{*}{ Sedang } & Rendah & $-4,5756$ & 2,34905 & 0.222 & $-10,8275$ & 1,6759 \\
\hline & Tinggi & $-10,6689 *$ & 1,87083 & 0,000 & $-15,6479$ & $-5,6899$ \\
\hline & Sangat Tinggi & $-10,1955^{*}$ & 2,28095 & 0,000 & $-16,2660$ & $-4,1250$ \\
\hline \multirow{3}{*}{ Tinggi } & Rendah & $6,0931^{*}$ & 2,07082 & 0,025 & 0,5818 & 11,6043 \\
\hline & Sedang & $10,6689 *$ & 1,87083 & 0,000 & 5,6899 & 15,6479 \\
\hline & Sangat Tinggi & 0,4734 & 1,99324 & 0,995 & $-4,8313$ & 5,7781 \\
\hline \multirow{3}{*}{ Sangat Tinggi } & Rendah & 5,6197 & 2,44766 & 0,113 & $-0,8945$ & 12,1338 \\
\hline & Sedang & $10,1955^{*}$ & 2,28095 & 0,000 & 4,1250 & 16,2660 \\
\hline & Tinggi & $-0,4734$ & 1,99324 & 0,995 & $-5,7781$ & 4,8313 \\
\hline
\end{tabular}

Hasil uji hipotesis dengan menggunakan anova dua jalur menunjukkan bahwa semua hipotesis penelitian diterima sehingga bisa dilakukan uji lanjut atau Post Hoc Test untuk mengetahui mana kategori keterampilan sosial yang memiliki perbedaan signifikan. Hasil uji Post Hoc dapat dilihat pada tabel 6. Berdasarkan tabel 6 dapat disimpulkan bahwa hasil belajar kelompok keterampilan sosial sangat tinggi, tinggi, dan rendah lebih bagus dibanding dengan kelompok keterampilan sosial sedang. Hasil belajar kelompok keterampilan sosial tinggi lebih bagus dibanding dengan kelompok keterampilan sosial sangat tinggi, sedang, dan rendah. Hasil belajar antara kelompok keterampilan sosial tinggi lebih bagus dibanding dengan kelompok keterampilan sosial sangat tinggi dan hasil belajar antara kelompok sosial rendah lebih bagus dibanding dengan kelompok keterampilan sosial sedang.

\section{PEMBAHASAN}

Pengaruh Model Pembelajaran Interaktif terhadap Hasil Belajar Kognitif Siswa dalam Pembelajaran Sejarah di SMA

Berdasarkan hasil pengujian hipotesis diperoleh nilai Sig. sebesar 0,005 < 0,05 sehingga dapat disimpulkan bahwa ada pengaruh positif signifikan penggunaan model pembelajaran interaktif terhadap hasil belajar siswa dalam pembelajaran sejarah. Hasil penelitian ini konsisten dengan hasil penelitian dari (Pada, 2016) dan melengkapi hasil penelitian dari (Vella \& Caruana, 2015). Hal ini menunjukkan bahwa model pembelajaran interaktif efektif diterapkan dan dapat memengaruhi hasil belajar siswa khususnya dalam pembelajaran sejarah. Hasil penelitian ini juga menunjukkan bahwa interaksi sosial memengaruhi perkembangan kognitif siswa seperti yang disebutkan dalam teori konstruktivistik sosial Vygotsky. 
Salah satu pemikiran Vygotsky dalam teori konstruktivistik sosial adalah Zone of Proximal Development (ZPD) perbedaan antara apa yang dapat dilakukan sendiri oleh anak dan apa yang dapat mereka lakukan dengan bantuan orang lain. Interaksi sosial yang dilakukan dengan guru dan teman sebaya dalam ZPD mendorong perkembangan kognitif siswa (Schunk, 2012). Faktor lain yang menyebabkan perolehan hasil belajar kognitif siswa yang menggunakan model pembelajaran interaktif lebih baik dibanding dengan siswa yang menggunakan model pembelajaran konvensional adalah adanya kerja sama atau kolaborasi dalam memecahkan suatu permasalahan dan mempelajari materi. Interaksi sosial yang siswa lakukan selama proses pembelajaran ini dapat berperan sebagai fungsi pengajaran (Schunk, 2012). Interaksi dalam proses pembelajaran seperti dalam model pembelajaran interaktif merupakan salah satu ciri pembelajaran yang efektif dan berhubungan dengan kualitas pembelajaran (Setyosari, 2017). (Koeshandayanto, 2013) menyebutkan bahwa strategi kooperatif yang didasarkan pada adanya interaksi atau dialog antar teman merupakan salah satu faktor penentu dalam keberhasilan pembelajaran. (Arends, 2012) juga menyebutkan bahwa pembelajaran kooperatif setidaknya dapat mengembangkan tiga hal penting, yaitu pencapaian akademik, toleransi, dan keterampilan sosial.

\section{Pengaruh Keterampilan Sosial terhadap Hasil Belajar Kognitif Siswa dalam Pembelajaran Sejarah di SMA}

Berdasarkan hasil pengujian hipotesis diperoleh nilai Sig. sebesar 0,000 < 0,05 sehingga dapat disimpulkan bahwa ada pengaruh positif signifikan keterampilan sosial siswa terhadap hasil belajar siswa dalam pembelajaran sejarah. Hasil uji hipotesis yang kemudian dilanjutkan dengan uji Post Hoc menunjukkan bahwa siswa yang memiliki keterampilan sosial tinggi memperoleh hasil belajar lebih baik dibanding dengan siswa yang memiliki keterampilan sosial sangat tinggi, sedang, dan rendah. Sedangkan siswa yang memiliki keterampilan sosial rendah memperoleh hasil belajar yang lebih baik dibanding dengan siswa yang memiliki keterampilan sosial sedang. Hasil penelitian ini relevan dengan hasil penelitian (Wahid, 2015), tetapi berbeda dengan hasil penelitian (Sutomo, 2016) yang menyebutkan tidak ada perbedaan hasil belajar siswa yang memiliki keterampilan sosial tinggi dengan siswa yang memiliki keterampilan sosial rendah. Perbedaan ini bisa disebabkan oleh instrumen yang digunakan berbeda, pembagian kategori keterampilan sosial yang berbeda, dan subjek penelitian yang berbeda.

Hasil penelitian ini juga menunjukkan bahwa ZPD yang dikemukakan dalam teori konstruktivistik Vygotsky memang dapat memengaruhi perkembangan kognitif siswa. (Santrock, 2011) menyebutkan bahwa ZPD menangkap keterampilan kognitif anak yang sedang dalam kedewasaan dan dapat dicapai hanya dengan bantuan orang yang lebih terampil. Bantuan ini dapat diterima dengan baik jika siswa memiliki keterampilan sosial yang baik. Hal ini juga sesuai dengan pendapat dari (Steedly, Schwartz, Levin, \& Luke, 2008) yang menyebutkan bahwa successful learning requires students to interact closely with teachers and peers. Keterampilan sosial membantu siswa dalam melakukan interaksi dalam proses pembelajaran. Berkaitan dengan hasil uji post hoc, diduga ada beberapa faktor yang memengaruhi, yaitu penggunaan model pembelajaran.

\section{Pengaruh Interaksi antara Model Pembelajaran Interaktif dan Keterampilan Sosial terhadap Hasil Belajar Kognitif Siswa dalam Pembelajaran Sejarah di SMA}

Berdasarkan hasil pengujian hipotesis diperoleh nilai Sig. sebesar 0,032 < 0,05 sehingga dapat disimpulkan bahwa ada pengaruh positif signifikan interaksi antara model pembelajaran interaktif dan keterampilan sosial siswa terhadap hasil belajar siswa dalam pembelajaran sejarah. Hasil penelitian ini melengkapi hasil penelitian sebelumnya yang tidak memadukan model pembelajaran interaktif dengan keterampilan sosial. Hasil penelitian ini melengkapi kekurangan hasil penelitian dari (Vella \& Caruana, 2015) bahwa keberhasilan model pembelajaran interaktif dalam memengaruhi hasil belajar karena siswa memiliki keterampilan sosial yang tinggi. Pada proses pembelajaran dengan menggunakan model pembelajaran interaktif, siswa harus melakukan kegiatan kooperatif yang membutuhkan interaksi dengan guru, teman satu kelompoknya, dan teman di luar kelompoknya ketika presentasi dan diskusi kelas dimulai. Keberhasilan kelompok dalam memahami materi bersama, memecahkan permasalahan yang diberikan guru, mempresentasikan hasil diskusi, dan menjawab pertanyaan ketika diskusi kelas tergantung dari kerja sama kelompok. (Johnson \& Johnson, 2017) menyebutkan bahwa cooperation is working together to accomplish shared goals. Within cooperative activities individuals seek outcomes that are beneficial to themselves and all other group members. Kerja sama dalam kelompok inilah yang membutuhkan keterampilan sosial siswa.

\section{SIMPULAN}

Berdasarkan hasil penelitian dan pembahasan dapat disimpulkan bahwa (1) ada pengaruh positif signifikan penggunaan model pembelajaran interaktif terhadap hasil belajar siswa dalam pembelajaran sejarah, (2) ada pengaruh positif signifikan keterampilan sosial siswa terhadap hasil belajar siswa dalam pembelajaran sejarah, dan (3) ada pengaruh positif signifikan interaksi antara model pembelajaran interaktif dan keterampilan sosial siswa terhadap hasil belajar siswa dalam pembelajaran sejarah.

Bagi guru disarankan untuk menggunakan model pembelajaran interaktif dalam pembelajaran sejarah sebagai alternatif lain selain model pembelajaran konvensional. Agar mendapatkan hasil yang maksimal dengan menggunakan model pembelajaran interaktif, guru disarankan untuk benar-benar melaksanakan pembelajaran sesuai dengan sintaks model pembelajaran interaktif 
dan benar-benar menguasai sumber belajar yang digunakan. Guru juga harus mengawasi kegiatan kooperatif siswa dan bisa membuat diskusi kelas menjadi aktif. Selain itu, dalam menggunakan model pembelajaran interaktif, guru juga perlu memperhatikan tingkat keterampilan sosial siswa dan membiasakan siswa untuk bisa berinteraksi sosial dalam proses pembelajaran.

Bagi peneliti selanjutnya, bisa mengembangkan penelitian ini menjadi Penelitian Tindakan Kelas. Peneliti selanjutnya juga bisa melakukan penelitian eksperimen dengan memadukan model pembelajaran interaktif dengan variabel lain, seperti motivasi berprestasi, kemampuan berpikir kritis, dan gaya berpikir siswa. Penelitian ini juga bisa dikembangkan dengan menggunakan variabel hasil belajar aspek afektif dan psikomotorik.

\section{DAFTAR RUJUKAN}

Aman, A. (2011). Model Evaluasi Pembelajaran Sejarah. Yogyakarta: Ombak.

Arends, R. I. (2012). Learning to Teach Ninth Edition. New York: Mc Graw Hill Book Co.

Arifin, Z. (2014). Evaluasi Pembelajaran: Prinsip, Teknik, Prosedur. Bandung: Remaja Rosdakarya.

Cartledge, G., \& Milburn, J. F. (1980). Teaching Social Skills to Children. Oxford: Pergamon Press.

Creswell, J. (2010). Research Design Qualitative and Mixed Qualitative Approach. Yogyakarta: Pustaka Pelajar.

Firmansyah, H., \& Kurniawan, S. (2017). Desain Pembelajaran Sejarah Berbasis Character Building. Yogyakarta: Ombak.

Fitriani, F., Wahjoedi, W., \& Towaf, S. M. (2017). Penerapan Model Kooperatif Tipe Make a Match Berbantuan Kartu Bergambar untuk Meningkatkan Keterampilan Sosial dan Hasil Belajar IPS. Jurnal Pendidikan: Teori, Penelitian, dan Pengembangan, 2(12), 1577-1584.

Koeshandayanto, S. (2013). Pengaruh Strategi Scaffolding-Kooperatif dan Pengetahuan Awal terhadap Prestasi Belajar dan Sikap pada Matakuliah Fisika Dasar. Jurnal Pendidikan Humaniora, 1(1), 70-80.

Pada, H. (2016). Pengaruh Model Pembelajaran Interaktif vs Model Pembelajaran Langsung dan Motivasi Berprestasi terhadap Hasil Belajar Membaca Pemahaman Wacana Bahasa Inggris Siswa SMP Kelas VIII Kupang Nusa Tenggara Timur. Skripsi tidak diterbitkan. Universitas Negeri Malang, Malang.

Santrock, J. W. (2011). Educational Psychology. New York: The McGraw-Hill Companies, Inc.

Sayono, J. (2015). Pembelajaran Sejarah di Sekolah: dari Pragmatis ke Idealis. Jurnal Sejarah dan Budaya, 7(1), 9-17.

Schunk, D. H. (2012). Teori-teori Pembelajaran: Perspektif Pendidikan (6th ed.). Yogyakarta: Pustaka Pelajar.

Setyosari, P. (2017). Menciptakan Pembelajaran yang Efektif dan Berkualitas. JINOTEP (Jurnal Inovasi dan Teknologi Pembelajaran) Kajian dan Riset Dalam Teknologi Pembelajaran, 1(1), 20-30.

Steedly, K. M., Schwartz, A., Levin, M., \& Luke, S. D. (2008). Social Skills and Academic Achievement.

Sugiyono, S. (2012). Metode Penelitian Pendidikan: Pendekatan Kuantitatif, Kualitatif, dan R\&D. Bandung: Alfabeta.

Sutomo, M. (2016). Pengaruh Strategi Pembelajaran Kooperatif Jigsaw, dan Keterampilan Sosial terhadap Hasil Belajar IPS SMP di Kabupaten Lumajang. Jurnal Ilmu Pendidikan, 23(1), 11-18.

Vella, Y., \& Caruana, R. (2015). Raising Performance in History Teaching While Improving Secondary Students' Essay Writing Skills. History Education Research Journal, 13(1), 118-131.

Wahid, A. (2015). Pengaruh Strategi Pembelajaran Kooperatif Jigsaw dan Keterampilan Sosial terhadap Hasil Belajar IPS di SDN Kabupaten Bangkalan. JINOTEP (Jurnal Inovasi dan Teknologi Pembelajaran): Kajian dan Riset Dalam Teknologi Pembelajaran, 3(1), 14-30. http://dx.doi.org/10.17977/um031v3i12016p014 